\title{
MEDIJSKE REPREZENTACIJE OVISNIKA I OVISNOSTI O PSIHOAKTIVNIM TVARIMA U DNEVNOM TISKU U HRVATSKOJ
}

\section{Ljiljana Kordić :: Hajrudin Hromadžić :: Jurica Karlić}

IZVORNI ZNANSTVENI RAD / DOI: 10.20901/ms.8.16.3 / PRIMLJENO: 31.03.2017.

SAŽETAK Ovaj članak pokušaj je artikulacije problema i provedbe analize načina reprezentiranja ovisnika i ovisnosti o psihoaktivnim tvarima u medijskim sadržajima. Provedena je kvantitativna $i$ kvalitativna analiza sadržaja odabranih dnevnih novina u Hrvatskoj (Jutarnji list, Večernji list $i 24$ sata) tijekom 2015. godine te podanaliza u ciljanom razdoblju (Mjesec borbe protiv ovisnosti), što je poslužilo za usporedbu dva različita ciklusa. Analizirana je medijska zastupljenost ovisnika i ovisnosti o psihoaktivnim tvarima, konotacija takvih medijskih sadržaja te pristup toj problematici. Dobiven je uvid u načine na koje su ovisnost i ovisnici o psihoaktivnim tvarima reprezentirani u odabranim medijima; otkriveno je koje implikacije i posljedice takve reprezentacije nose sa sobom, zbog čega do takvih reprezentacija uopće dolazi te čiji su interesi zastupljeni u takvim reprezentacijama.

KLJUČNE RIJEČI

Bilješka o autorima

Ljiljana Kordić :: Udruga za pomoć ovisnicima „Vida“, Rijeka :: Ijkordic@gmail.com

Hajrudin Hromadžić :: Sveučilište u Rijeci, Filozofski fakultet :: hhromadzic@ffri.hr Jurica Karlić :: nezavisni istraživač :: jurica.karlic@gmail.com 


\section{UVOD}

Ovisnost je problem koji seže u sve pore društva, a uzroci i posljedice mogu se iščitavati u različitim kontekstima: medicinskom, kriminalističkom, sociološkom, psihološkom, ekonomskom i politološkom. Izvješće Vladina Ureda za suzbijanje zlouporabe droga (Vlada $\mathrm{RH}, 2015)$ procjenjuje kako mediji nisu posvetili dovoljno pozornosti toj temi, da je način na koji mediji pristupaju temi ovisnosti negativan i senzacionalistički (Vlada RH, 2015: 37) te kako postoji nedovoljno zanimanje medija za teme resocijalizacije ovisnika (Vlada $\mathrm{RH}, 2015:$ 33).

Ovaj rad pokušaj je artikulacije problema i provedbe analize načina reprezentiranja ovisnika i ovisnosti s ciljem ispitivanja obrazaca medijskog izvještavanja o ovisnosti o psihoaktivnim tvarima i ovisnicima u hrvatskim dnevnim novinama tijekom 2015. godine i posebno tijekom Mjeseca borbe protiv ovisnosti (svake godine od 15. studenog do 15. prosinca) (Vlada RH, 2017), kao i eventualne razlike u izvještavanju s obzirom na medijskog nakladnika. Provedena je kvantitativna i kvalitativna analiza sadržaja odabranih dnevnih novina u Hrvatskoj (Jutarnji list, Večernji list i 24 sata) tijekom 2015. godine, korištenjem slučajnog sustavnog uzorka te podanalizom u ciljanom razdoblju (Mjesec borbe protiv ovisnosti), što je poslužilo za usporedbu dva različita ciklusa. Dobiven je uvid u načine na koje su ovisnost, kao i ovisnici o psihoaktivnim tvarima, reprezentirani u odabranim medijima; otkriveno je koje implikacije i posljedice takve reprezentacije nose sa sobom, zbog čega do takvih reprezentacija uopće dolazi te čiji su interesi zastupljeni u takvim reprezentacijama.

\section{TEORIJSKA POLAZIŠTA}

\section{Ovisnost iz perspektive društvenih znanosti}

Ovisnost o psihoaktivnim tvarima kao društveni fenomen moguće je i potrebno sagledavati iz sociološkog, psihološkog i pedagoškog rakursa. Erich Goode (2014) primjećuje da se načini definiranja ovisnika i ovisnosti o drogama radikalno razlikuju ne samo među različitim društvima već i među partikularnim grupama i supkulturama unutar istog društva. To znači da različite društvene skupine i kulture, u različitim epohama, različito definiraju koje su droge prihvatljive, a koje ne, kao i tko i kada, pod kojim uvjetima i u kojim kontekstima, može konzumirati određene droge. Na tragu toga Goode nudi vrlo općenitu, tipično sociološku definiciju droge kao određenog tipa supstanci koje su od određenih segmenata društva arbitrarno definirane kao droge (Goode, 2014).

Sociološki, ovisnost tretiramo polazeći od tri koncepta (prema Lalić, 1995). Prvi je koncept totalnog društvenog fenomena, koji je inaugurirao Marcel Mauss, a dodatno razradio Georges Gurvitch, u okviru kojeg ovisnost ima svoj zatvoren i strukturirani društveni svijet koji se zrcali na više razina - kulturalnoj, fiziološkoj, ekonomskoj itd. Ovisnost u tom kontekstu isključuje vanjski društveni svijet, to jest norme karakteristične za vanjski svijet i njegovu kulturu. Drugi je koncept društvenog problema, karakterističan za funkcionali- 
stičku teorijsku orijentaciju. Većina sociologa koji koriste taj koncept fenomen ovisnosti promatraju kroz tri obilježja: 1. nepoželjan je sa stajališta javnosti i(li) dominantne skupine; 2. karakterističan je za veliki broj ljudi; 3. može se ublažiti ili spriječiti organiziranom društvenom akcijom (ibid.). Naknadno se pridodaje i četvrto obilježje, a to je šteta koju taj fenomen donosi na općedruštvenoj i individualnoj razini (ibid.). Treći sociološki koncept na fenomen ovisnosti gleda kao na društvenu devijaciju, ponašanje koje odstupa od onoga što se u društvu smatra normalnim i poželjnim. Kontroverze oko takvog koncepta uporište imaju u dvojbenosti ocjenjivanja određenog ponašanja kao nenormalnog i nepoželjnog. Takav tip kontroverzi zorno se manifestira u sklopu teorijskog koncepta etiketiranja kojim se, primjerice, koriste predstavnici interakcionističke orijentacije (sve prema Lalić, 1995). Sociološka istraživanja ovisnosti često se baziraju i na proučavanju života mladih i saniranju patologije među mladima, osobito aspekata ovisnosti, s ciljem obogaćivanja socijalnih interakcija s mladima i uspostavljanja društvenog reda u tim skupinama (Leburić i Relja, 2001).

Iz perspektive psihologije ovisničko ponašanje, zloupotreba psihoaktivnih tvari i ovisnost nose značajan socijalni i zdravstveni rizik. Ovisničko se ponašanje u psihologiji definira kao skup obrazaca ponašanja koji su autodestruktivni, koji imaju apetitivnu prirodu, opsesivno-kompulzivnu kvalitetu, značajnu fiziološku ili biološku komponentu, a koji se doživljavaju teško prilagodljivim i gotovo nezaustavljivim (Pačić-Turk i Bošković, 2008). Suvremena psihologija ističe kako svatko može postati ovisnik. Pored "klasičnih" psihoaktivnih tvari, heroina, morfija, amfetamina, tableta za smirenje i kokaina, navode se i nikotin, kofein, šećer, steroidi te se uvodi problematika novih ovisnosti - o internetu, poslu, vježbama, pa čak i o seksu (Grant i sur., 2010). Na ovisnost se gleda primarno kao na kompleksan fenomen, za čije je razumijevanje potreban interdisciplinarni pristup.

Sa stanovišta pedagogije ovisnost se proučava kroz prizmu prevencije ovisnosti o drogama (Bognar, 2005). Analizirana je zloupotreba opojnih droga među adolescentima te je ispitano kakav utjecaj takvo ponašanje ima na školovanje i odrastanje. U sklopu pedagoških studija naglasak je često stavljen na zloupotrebu droga i fizičko nasilje kod srednjoškolskih učenika te na zastupljenost maloljetnika i mlađih punoljetnika u strukturi prijavljenih počinitelja kaznenih djela zloupotrebe opojnih droga (Nenadić Bilan, 2012). Nadalje, kada je riječ o odnosu medija i mladih, koji čine pretežit dio populacije ovisne o drogama, analizirana je kvaliteta korištenja masovnih medija, vrijednosni sustav djece, njihov odnos prema društveno neprihvatljivim ponašanjima u korelaciji sa sociodemografskim obilježjima poput obiteljske situacije djece, školskog okruženja i načina korištenja slobodnog vremena (više o rezultatima tog istraživanja u llišin i sur., 2001).

\section{Ovisnost iz perspektive medijskih studija}

Posljednjih nekoliko desetljeća na medije se, istraživački i teorijski, ne gleda više kao na puke čimbenike prijenosa informacija, već kao na ključne faktore prilikom kreiranja društvene realnosti. Riječima Tonyja Bennetta, „mediji nisu odvojeni od društvene realnosti, u smislu da pasivno reflektiraju i vraćaju svijetu njegovu vlastitu sliku“, već upravo suprotno, „oni su dio društvene realnosti, doprinoseći njezinim obrisima, logici i smjernici 
njezina razvoja pomoću socijalno artikuliranog načina putem kojeg mediji oblikuju naše percepcije" (Bennett, 1982: 286). Stuart Hall, za razliku od Bennettova funkcionalističkog smjera, zauzima više ideološki pristup ovim pitanjima - on će ustvrditi da su „masovni mediji kolonizirali kulturalnu i ideološku sferu te da reproduciraju slike, reprezentacije i ideje oko kojih društvena realnost, sastavljena od odvojenih i segmentiranih dijelova, može biti koherentno obuhvaćena kao cjelina" (prema Hromadžić, 2013: 64).

Analizom medijskih reprezentacija dolazimo do saznanja o uvjetima i modelima putem kojih se društvena realnost konsolidira u one oblike koje poimamo kao okvire naših općih realnosti i koje zajednički dijelimo. Ta teza, primijenjena na stavove o marginaliziranju i demoniziranju ovisnika u medijskim sadržajima, upravo je bliska zaključcima istraživanja Tonyja Bennetta. Označavanjem marginaliziranih skupina - ovisnika o drogama, kriminalaca, nogometnih huligana, homoseksualaca - „otpadnicima koji ugrožavaju društvo", mediji pridonose jačanju dominantnih društvenih normi, stvarajući time povoljniju klimu - moralnu paniku - za podršku djelovanju zakonodavnih institucija kojima je tako delegirana još veća moć (Bennett, 1982: 295). Na taj način, ideološkim kodiranjima, mediji kreiraju slike društvene zbilje.

Takvim uvidima dolazimo do jednog od važnih okvira koji određuje i naš pristup u analizi teme kojom se bavi ovaj rad. Radi se o senzacionalističkom medijskom izvještavanju prilikom obrade problema ovisnika i ovisnosti o psihoaktivnim tvarima. Pojam senzacionalizam, u medijskom smislu, označava trendove pojačanog uredničkog i novinarskog tretiranja društvenih događaja u vidu izvještavanja i priča koje će prema procjeni medijskih radnika - ali prije svega vlasnika medija! - uzrokovati povećan interes javnosti, odnosno medijskih publika, a time će biti zanimljive i za glavne poslovne suradnike većine današnjih medija srednje struje (engl. mainstream media) - oglašivače, to jest korporativne subjekte. Prilozi takvog tipa u medijima intonirani su bombastično, spektakularno, apokaliptično ili katastrofično, svakako s adrenalinskim nabojem. Često su temeljeni na intrigama, tračevima, spletkama i „malim ljudskim pričama“, odnosno za javnost irelevantnim trivijalnim tabloidnim naracijama koje provjereno prouzrokuju emocionalne efekte među publikama, poput straha ili ushićenosti. Pritom se nerijetko zanemaruju čak i minimumi klasičnih novinarskih profesionalnih standarda u vidu provjerenih podataka, tvrdih argumenata, racionalnih, trezvenih prosudbi i zaključaka na temelju obrađenih i utvrđenih činjenica, a ne dojmova ili laži, sve s ambicijom poslovno-profitnog profila: biti ekskluzivniji, brži, zanimljiviji, zabavniji... od konkurencije na tržištu.

Premda nam neke istraživačke studije nude saznanja da su takvi trendovi puno starijeg datuma, da sežu sve do starorimskih Acta Diurna, dnevnih oglasnih objava u starome Rimu koje su, među ostalim, sadržavale i elemente senzacionalizma, pa preko određenih tipova književnih uradaka iz 16. i 17. stoljeća (više u Stephens, 2007), uznapredovale trendove medijskog senzacionalizma bilježimo tijekom posljednjih pola stoljeća u masovnoj medijskoj produkciji, bez bitnih razlika kada su u pitanju javni ili komercijalni mediji. $\mathrm{Na}$ kritike takvih trendova često se odgovara frazom „ali ljudi takve sadržaje jednostavno žele", i to se onda potkrepljuje navodno objektivnim statistikama o rejtinzima gledanosti, posjećenosti mrežnih stranica, čitanosti... Ono što se pritom „zaboravlja” jest da su ljudi 
bića koja se uče nešto željeti, educiraju se o onome „što žele“ i socijaliziraju se. Odnosno, želja je sociološka, a ne biološka kategorija, no potrošačko-medijska kapitalistička kultura 20. i 21. stoljeća tretira je kao nešto prirodno iz financijsko-profitnih razloga.

Otprilike $u$ isto vrijeme, 70-ih godina prošlog stoljeća, medijski su studiji sve više istraživačkih interesa započeli pridavati spomenutim trendovima, svodeći ih pod objedinjujuću konceptualnu sintagmu „kreiranje moralne panike“. Ključni autor koji je postavio temelje za proučavanje odnosa medija i moralne panike jest Stanley Cohen. U već klasičnoj studiji Folk Devils and Moral Panics, prvi put objavljenoj 1972., Cohen je postavio tezu po kojoj do kreiranja stanja moralne panike dolazi u situacijama kada pojedinci ili čitave društvene skupine bivaju etiketirani kao prijetnja normativnom poretku zajednice, u čemu mediji imaju nezaobilaznu ulogu i odgovornost (prema Cohen, 2002). Taj će koncept doživjeti široku prihvaćenost i poslužit će kao platforma za istraživanja brojnih suvremenih fenomena ovog tisućljeća poput terorizma, školskog nasilja vatrenim oružjem u SAD-u, reafirmiranih strahova oko seksualnog ropstva, trgovine ljudima i tomu slično (više u Goode i Ben-Yehuda, 2009). Uloge „pučkih demona“ (engl. folk devils), na različite načine kreirane i potom mehanizmima medijskog spina naširoko distribuirane u stilu svojevrsne moralne panike, redovito pripadaju ovisnicima o narkoticima, što ćemo u nastavku članka potkrijepiti konkretnom analizom.

Na kraju ovog kraćeg teorijskog okvira iz perspektive medijskih studija za analizu fenomena prikaza ovisnosti i ovisnika o narkoticima u medijima, konkretno u dnevnim novinama u Hrvatskoj, a na osnovi svega prethodno iznesenog, nameće se pitanje koje se nalazi u temeljnim postavkama ovakvog istraživanja, a to je pitanje vjerodostojnosti medija. Možemo li, i pod kojim uvjetima, uopće još povezivati kvalitativnu odrednicu vjerodostojnost s današnjim prevladavajućim medijima? ${ }^{1}$

\section{METODE ISTRAŽIVANJA}

Svrha ovog rada jest potaknuti raspravu o medijskim reprezentacijama ovisnika i ovisnosti o psihoaktivnim tvarima. Cilj je ispitati obrasce medijskog izvještavanja o ovisnosti o psihoaktivnim tvarima i ovisnicima u hrvatskom dnevnom tisku tijekom 2015., a posebno tijekom Mjeseca borbe protiv ovisnosti (koji se obilježava svake godine od 15. studenog do 15. prosinca), kao i eventualne razlike u izvještavanju s obzirom na medijskog nakladnika. Osnovno istraživačko pitanje jest u kolikoj je mjeri i na koji način zastupljena tema ovisnosti o drogama u odabranim dnevnim novinama u Hrvatskoj.

Kao izvori analize odabrane su dnevne nacionalne novine Večernji list, Jutarnji list i 24 sata. Jutarnji list i Večernji list su danas, uz 24 sata, jedine novine s nacionalnim dosegom te su pritom i najčitanije dnevne novine. Prema podacima agencije Ipsos Puls o čitanosti tiskanih medija u 2015. godini, a koje je objavio Jutarnji list na svom portalu, Jutarnji list bilježi rastući trend, dok je Večernji list pao s 8,6 \% po broju u siječnju 2015. na 7,4 \% u srpnju 2015. Jutarnji list $u$ istom periodu drži stabilnu prosječnu čitanost od 8,2 \%. Ako pak govorimo o

\footnotetext{
$\overline{1}$ Za potpuniji uvid u koncept vjerodostojnosti medija, odnosno vjerodostojnosti novina u regionalnom kontekstu, pogledati Malović (2007).
} 
dosegu novina, u srpnju 2015. Jutarnji list bilježio je 20,3 \%, a Večernji list 18,2 \%. Novine 24 sata prednjače u dnevnom dosegu s 22,8 \% (Bratić, 2014). Jutarnji list i Večernji list naizgled su slične vizualne prezentacije, pripadaju različitim vlasnicima i karakterizira ih drukčija uređivačka politika, dok je list 24 sata manjeg formata, niže cijene i tabloidnog karaktera. ${ }^{2}$

Zašto pristupamo analizi sadržaja dnevnog tiska, a ne sve utjecajnijih internetskih portala i društvenih mreža? Dnevni je tisak, iako mu je, statistički gledano, čitanost u konstantnom opadanju ${ }^{3}$, i dalje jedan od glavnih izvora informacija. Mlađe populacije, koje su najčešće zahvaćene problemom ovisnosti, preferiraju online informiranje i zabavu ${ }^{4}$, no internetski preglednici i pretraživači najčešće preusmjeruju čitatelje na internetska izdanja nacionalnog dnevnog tiska i njihove internetske portale. Nadalje, demografska slika stanovništva u Hrvatskoj pokazuje trend rasta stanovništva starije dobi ${ }^{5}$, dakle populacije koja tradicionalno svoje informiranje u značajnoj mjeri bazira i na čitanju dnevnog tiska. Vođeni činjenicom da dnevni tisak u hrvatskom društvu gaji tradiciju i učestalost u informiranju javnosti, možemo pretpostaviti zbog čega je analiza sadržaja dnevnog tiska o temi ovisnosti relevantnog karaktera.

Pored toga, prethodno smo već spomenuli kako u medijskoj teoriji postoji konsenzus o tome da vijesti nisu kopija stvarnosti ili logična posljedica događaja koji je po sebi vrijedan da se objavi, nego društveni proizvod (više o tome u Hromadžić, 2014). Prikaz stvarnosti koju nudi vijest nije sama stvarnost, nego je to stvarnost generirana putem sustava znakova koji se odnose na društvene strukture. Vijesti su primjer "jezika-u-uporabi" socijalno strukturiranog smisla (Harley, 2007). One podjednako i oblikuju i odražavaju glavnu predodžbu o tome što je značajno i stoga doprinose aktualnom procesu izgradnje dominantnih ideologija putem kojih publika percipira realnost.

U ovom istraživanju provedena je kvantitativna analiza sadržaja članaka koji su objavljeni u odabranom hrvatskom dnevnom tisku, koja je potom nadograđena i kvalitativnim

\footnotetext{
$\overline{2}$ Vlasnička struktura analiziranih novina, iz koje bi se mogla iščitati svjetonazorska i uređivačka politika, zamršena je i netransparentna. Hrvatska gospodarska komora na svojim mrežnim stranicama omogućuje pristup dokumentu koji sadrži popis novinskih nakladnika, ali navodi samo ime tvrtke koja je vlasnik naklade. Ukratko, što se tiče cirkulacije i čitanosti, dominira austrijska kompanija Styria s izdanjima 24 sata i Večernji list, a slijedi EPH (Europapress holding) sa svojim izdanjem Jutarnji list. No premda je Styria pronašla način uspješnog približavanja čitateljima sa svojim tabloidom 24 sata, najjeftinijim dnevnim novinama u Hrvatskoj, EPH je dugo bio dominantan igrač na tržištu jer je, uz druge tjednike i mjesečnike, izdavao i dnevni list Slobodna Dalmacija, najuspješniji tjednik za žene Gloriju te politički magazin Globus (sve prema Popović, 2014: 76). EPH je doživio preustroj vlasničke strukture u posljednjih nekoliko godina te je nakon predstečajne nagodbe i sudskog procesa protiv bivšeg suvlasnika Ninoslava Pavića EPH kupio zagrebački odvjetnik Marijan Hanžeković. EPH se potom reorganizira, a Hanza Press Marijana Hanžekovića 2015. godine postaje vlasnik 90 \% vlasničkog udjela. Novo vodstvo najavilo je kako bi Jutarnji list koncepcijski trebao biti glasilo liberalnog, socijaldemokratskog usmjerenja, s težištem na točnosti i relevantnosti (PoslovniPuls, 2015). Vlasnik Večernjeg lista i 24 sata, austrijski medijski koncern Styria Medien AG, u Hrvatskoj ima u vlasništvu još dva dnevna lista, Poslovni dnevnik i TV tjedan, portal Njuskalo.hr, a vlasnik je i Tiskare Zagreb, jedne od najvećih i najmodernijih tiskara u Hrvatskoj.

3 Podaci pokazuju da je u razdoblju od 2009. do 2014. tržište postalo siromašnije za troje novina, dok je ukupna naklada od 2008. do 2014. pala za čak $53 \%$ (Vozab, 2014: 140).

4 Prema istraživanju koje je proveo Institut za društvena istraživanja u Zagrebu u suradnji sa Zakladom Friedrich Ebert Stiftung u Zagrebu, a kojim je rukovodila Vlasta Ilišin, kulturu današnjih mlađih generacija dominantno obilježavaju internetski medijski sadržaji. Najviše slobodnog vremena provode na internetu, vrlo rijetko idu u kazalište, a samo ih jedna četvrtina redovito čita knjige. Istraživanje pod nazivom „Perception and attitudes of young people towards the changing reality“ provedeno je 2012., a obuhvatilo je srednjoškolski uzrast u nekoliko zagrebačkih gimnazija (Ilišin i sur., 2013).

${ }^{5}$ Prema redovitim podacima hrvatskog Državnog zavoda za statistiku, stanovništvo sve brže stari. Tako je očekivana životna dob za žene u Hrvatskoj danas 80 godina, a 73 za muškarce. Prosječna se starost s 30,7 godina prije šezdesetak godina povisila na 41,7 godina. U dobi od 60 i više godina danas je gotovo četvrtina stanovnika Hrvatske (24\%), a prije pedesetak godina taj je udio iznosio $12 \%$ (više na www.dzs.hr).
} 
istraživačkim pristupom - analizom medijskog sadržaja. Prema Bernardu Berelsonu „analiza sadržaja jest tehnika istraživanja objektivnog, sistematskog i kvantitativnog opisa manifestnoga sadržaja sredstava komuniciranja“" (prema Dragojević i sur., 2004: 99).

Za jedinicu analize uzet je jedan prilog u kojem se spominje neki aspekt ovisnosti ili bilo koji pojam vezan uz ovisnost i droge, to jest naslov, podnaslov i najava teksta na naslovnoj stranici, članak, kao i slikovni materijali uz članak. U glavnoj analizi koristio se slučajni sustavni uzorak, odnosno odabran je za pregled svaki deseti dan tijekom 2015. godine. U uzorak su ušli svi članci u kojima se spominju neki aspekti ovisnosti - droge, alkohol, posljedice zlouporabe opojnih sredstava, zaplijene, zakoni vezani uz ovisnost, te osobe u vezi s navedenim - ovisnici, njihove obitelji, djeca, najčešće u kontekstu prometa, posla i obiteljskog života. Analizirano je 116 članaka. Provedena je i podanaliza dnevnog tiska tijekom svih 30 dana u Mjesecu borbe protiv ovisnosti (15. 11. - 15. 12.). Analizirano je 75 članaka.

Analiza sadržaja provedena je, kako u glavnoj tako i u podanalizi, s obzirom na vrijednosnu orijentaciju naslova članaka, novinarske forme i žanrove, novinske rubrike u kojima su članci objavljeni, temu novinskog članka, prosjek prostora članka na stranici dnevnih novina te sadržaj teksta članka i opremu teksta. Populaciju ili skupinu jedinica na koje se istraživanje poopćuje čine članci objavljeni u hrvatskom dnevnom tisku u kojima se spominju ovisnost ili neki aspekti ovisnosti.

Analizu sadržaja provela su dva ocjenjivača. Razina pouzdanosti analize ispitana je Cohenovim Kappa koeficijentom. Medijan koeficijenta za sve kategorije analize od 0,74 ukazuje na zadovoljavajuću razinu pouzdanosti. Analitička matrica, konstruirana tijekom izrade istraživačkog nacrta, sadržavala je sedam klasifikacijskih kategorija:

1. Vrijednosna orijentacija naslova članaka: neutralna orijentacija (za članke koji nepristrano i bez određenih tendencija izvještavaju o određenom događaju), pozitivna orijentacija (za naslove koji temu ovisnosti predstavljaju u pozitivnijem tonu, odnosno gdje se prikazuju primjeri kvalitetne borbe protiv ovisnosti i pozitivni primjeri izlaska iz ovisničkog života) i negativna orijentacija (u kojima je ovisnička tema fokusirana na kriminalne radnje, divljaštvo, vožnje u teško alkoholiziranim stanjima, obiteljsko zlostavljanje i sl.).

2. Novinarske forme i žanrovi: vijest, izvještaj, reportaža, intervju, komentar, analiza, te kolika je prosječna zastupljenost članaka u pojedinim formama.

3. Novinske rubrike u kojima su članci objavljeni. Analizirana je pozicija članka s obzirom na rubriku u kojoj se nalazi: vijesti, crna kronika, novosti, spektakl, sport, zabava, poslovni svijet, aktualno, najave i sl.

4. Tema novinskog članka u kojemu se spominje ovisnost ili bilo koji pojam vezan uz ovisnost i droge. Ta se kategorija referira na sadržaje poput zapljene narkotika, remećenja javnog reda pod utjecajem opojnih sredstava, vožnje pod utjecajem raznih opojnih sredstava, policijskih izvještaja, intervjua liječenih ovisnika, života slavnih vezanih uz konzumacije narkotika i sl. 
5. Prosjek prostora članka na stranici dnevnog tiska. Kategorija u čijem su fokusu pitanja koliki je postotak prostora koji zauzima pojedini članak na novinskoj stranici te što njegova veličina govori o važnosti vijesti i koje konotacije njegova pozicija na stranici sugerira.

6. Sadržaj članka. Tu su naglašena pitanja o tome je li članak napisan na senzacionalistički način i koliko se sadržaj podudara s naslovom članka. Senzacionalistički pristup definirali smo kao naglašavanje trivijalnih informacija i događaja u novinskom sadržaju, a koji se predstavljaju kao važni ili značajni: naslov članka nije u skladu sa sadržajem teksta; sadržajem se zadire u privatni život; članak sadrži uznemirujuće fotografije unesrećenih osoba; vrijeđaju se druge osobe; površnost u izvještavanju te izostavljanje konteksta.

7. Grafička oprema teksta članka: naslov, nadnaslov, podnaslov, okvir unutar članka, fotografije, tekst u boji, komentari uz sliku i sl.

\section{REZULTATI ANALIZE SADRŽAJA}

\section{Rezultati analize priloga iz uzorka uzetog tijekom 2015. godine}

Postotak dana s člancima koji imaju za temu ovisnost ili sadrže bilo koji pojam vezan uz ovisnost i droge tijekom razdoblja koje je obuhvaćeno glavnom analizom, a u odnosu na 37 dana koji su ušli u uzorak, u Jutarnjem listu iznosio je 75,68 \% (28 dana), dok je u Večernjem listu i 24 sata bio nešto niži, 59,46 \% (22 dana) i 54,05 \% (20 dana).

Iščitavajući sadržaj članaka te njihovu poziciju u dnevnom tisku, možemo zaključiti da se velika većina sadržaja odnosi na kratke vijesti u rubrikama crne kronike, ponajprije vezane uz temu zapljene narkotika i prometnih prekršaja pod utjecajem opojnih sredstava, te na kratke izvještaje o kriminalnom miljeu, zdravstvenim posljedicama i dobrobiti pojedinih supstanci. Analiza sadržaja temeljila se na uzorku u koji su ušli svi članci vezani za bilo koji aspekt ovisnosti. No, da rezultate kvantitativnog dijela istraživanja ne smijemo uzeti kao pravi smjerokaz reprezentacije ovisnosti i ovisnika, pokazuje primjer članka pod naslovom „10 CM KRAĆl: Dječaci koji puše „travu“ manje rastu“, u kojem piše:

Dječaci koji puše marihuanu prije nego što dođu u pubertet mogli bi narasti manje nego njihovi vršnjaci, kaže nova studija. Mladi koji su ovisni o ovoj drogi narast će čak 10 centimetara manje, a zbog konzumacije kanabisa bit će i za 4 do 5 kilograma lakši od svojih vršnjaka. Pušenje trave umjesto da opušta, navodi se, na duge staze zapravo uzrokuje veće nezadovoljstvo jer uzrokuje veće lučenje hormona stresa - kortizola (Jutarnji list, 20.05.2015.a: 32)

Zbog toga se naša analiza nije zadržala samo na kvantitativnoj obradi podataka već uključuje i kvalitativnu analizu sadržaja. Stavljajući u parametre istraživanja riječi navedenog članka, vezanih uz temu ovisnosti - kao npr. marihuana, ovisni, droga, kanabis, trava - dobiveni rezultati govorit će u prilog velikoj i primjerenoj zastupljenosti tema ovisnosti. No sagledamo li članak u cjelini i proučimo kontekst u kojem je napisan te diskurs koji je korišten, razumjet ćemo potrebu za kvalitativnim istraživačkim pristupom i kritičkom perspektivom prilikom obrade sadržaja. 
Usporedo s postotkom dana koji sadrže članke vezane uz temu ovisnosti, izračunat je i postotak članaka u pojedinačnom tisku u odnosu na ukupan broj analiziranih članaka. Najveći postotak članaka vezanih uz ovisnost nalazi se u Jutarnjem listu (42,24 \%), dok je nešto niži u Večernjem listu (30,17 \%) i u 24 sata (27,59\%). Postotak dana s člancima koji se odnose na temu ovisnosti povezan je i s postotkom prostora na novinskoj stranici objavljenih članaka vezanih uz ovisnost. Kako se vidi u tablici 1, najviše prostora u prosjeku zauzimaju članci objavljeni u 24 sata, 61,27 \% prostora stranice, a najmanje članci objavljeni u Večernjem listu (20,87 \%), dok u Jutarnjem listu prosječno zauzimaju 38,81 \% prostora.

Tablica 1. Postotak prostora priloga vezanih uz temu ovisnosti na novinskoj stranici

\begin{tabular}{lll} 
Dnevne novine & $\begin{array}{l}\text { \% prosjeka prostora na stranici } \\
\text { objavljenih priloga }\end{array}$ & Dimenzije stranice u mm \\
\hline Jutarnji list & $38,81 \%(103 \times 150 \mathrm{~mm})$ & $265 \times 386 \mathrm{~mm}$ \\
Večernji list & $20,87 \%(52 \times 73 \mathrm{~mm})$ & $249 \times 350 \mathrm{~mm}$ \\
24 sata & $61,27 \%(123 \times 128 \mathrm{~mm})$ & $200 \times 275 \mathrm{~mm}$ \\
\hline
\end{tabular}

Valja naznačiti da prosjek prostora ne daje realnu sliku zastupljenosti tema ovisnosti i koliki one prostor zauzimaju na stranicama dnevnog tiska. Uz priloženu statistiku valja napomenuti kako je postotak prosjeka uglavnom određen velikim prostorom koji zauzimaju senzacionalistički članci poput "Dječak pušio osvježivač zraka, poplavio i umro?" (24 sata, 20.02.2015.: 4), koji se proteže na četiri stranice i u kojem se istražuju uzroci smrti mladića uz detaljnu analizu tržišta legalnih psihoaktivnih supstanci. Primjer je i članak naslova „U Hrvatskoj se pere golemi novac moćnih narkokartela" (Jutarnji list, 07.09.2015.: 7), koji iskorištava negativnu i senzacionalističku konotaciju vezanu uz narkosvijet kako bi privukao publiku na čitanje novinskog izvještaja o financijskim malverzacijama privatnih biznismena u Hrvatskoj i promovirao kapitalistički diskurs kao prikladan u analiziranju trenutnog stanja na ekonomskom tržištu.

Većina članaka ipak se odnosi na kratke vijesti, vijesti u crnoj kronici, vijesti iz svijeta slavnih i na zanimljivosti iz širokog spektra društvenih zbivanja, gdje se postotak prosjeka prostora kreće od $4 \%$ do $15 \%$, a naslovi, uz negativnu konotaciju spram pitanja ovisnosti, uglavnom iskorištavaju „najsočniji“ dio izvještavanog događaja, poput: „Drogirani par divljao držeći bebu“ (Jutarnji list, 20.05.2015.b: 18), „Policija spaljivala marihuanu pa se pola grada napušilo" (Večernji list, 31.03.2015.: 48) te "Maloljetnik dodatni džeparac zarađivao dilanjem tripova" (24 sata, 21.04.2015.: 15).

Kada govorimo o poziciji stranice na kojoj su članci objavljeni, treba reći da je u Jutarnjem listu samo jedan članak najavljen na naslovnici: „Kako nam je marihuana spasila živote" (Jutarnji list, 27.09.2015.). Riječ je o članku o medicinskoj marihuani i slučaju Huanita Luksetića, oboljelog od multiple skleroze. U Večernjem listu također je jedan članak najavljen na naslovnici - "Mitovi o kanabisu“ (Večernji list, 18.08.2015.). Radi se o naslovnoj najavi članka o legalizaciji medicinske marihuane. Novine 24 sata imaju tri članka vezana uz ovisnost koja su najavljena na naslovnici: „Djed (63): Marihuana je bakina, ja joj uopće nisam 
pomagao" (24 sata, 31.01.2015.), "Dječak pušio osvježivač i umro“ (24 sata, 20.02.2015.) te "Nova droga u gumenim bombonima" (24 sata, 20.07.2015.) i svi su senzacionalistički orijentirani. U sva tri dnevna lista mjesto na naslovnoj stranici zauzele su teme vezane uz marihuanu, odnosno uz promoviranje legalizacije medicinske marihuane. To upućuje na moguće konotacije koje iščitavamo iz promoviranja određenih tema u sklopu uređivačkih politika i koliko privatni biznis te politička struktura imaju utjecaja na odabir "gorućih" tema, u ovom slučaju to je promocija medicinske marihuane kroz farmaceutsku industriju.

Naveli smo već kako je postotak dana s člancima u kojima se spominje neki aspekt ovisnosti ili bilo koji pojam vezan uz ovisnost i droge iznenađujuće visok, no kao što je vidljivo iz tablice 2, prosječan broj članaka po izdanju izrazito je nizak. Najviši prosjek ima Jutarnji list s 1,75 članaka po dnevnom izdanju, dok su Večernji list i 24 sata izjednačeni s 1,6 članaka po izdanju.

Tablica 2. Prosječan broj članaka s tematikom ovisnosti po izdanju tijekom 2015. godine

\begin{tabular}{ll} 
Dnevne novine & Prosjek \\
\hline Jutarnji list & 1,75 \\
Večernji list & 1,59 \\
24 sata & 1,60 \\
\hline
\end{tabular}

Valja istaknuti kako je taj broj članaka po dnevnom izdanju sveden na informacije ne toliko vezane uz realne probleme ovisnosti (informiranje i savjetovanje javnog mijenja o trenutnom stanju marginalizirane skupine), već se kroz kratke vijesti i izvješća uglavnom promovira senzacionalistički diskurs koji iskorištava temu ovisnosti kao okidač koji privlači čitateljevu pažnju. Takav je naslov članka "Mladi par umro nakon pira od nove smjese narkotika" (Večernji list, 27.10.2015.). Naslov i tema članka vođeni su senzacionalističkom konstrukcijom vijesti, gdje se tekst članka uopće ne referira na ovisnost niti je sadržaj teksta vezan uz kobne posljedice zloupotrebe droga. Članak se sastoji od policijskog izvještaja i nekoliko kratkih biografskih podataka mladog para te okolnosti u kojima se tragedija dogodila. Samo se u kratkom dijelu članka ističe neopravdana sumnja u kobne posljedice konzumiranja opijata. Činjenično stanje govori da se mladi par otrovao u snu plinom koji je kroz loše instalacije uspio prodrijeti u njihovu spavaću sobu. Dakako, ovo je i jedan od primjera negativno konotiranih članaka.

Dobiveni podaci nam govore da je oko polovice ispitanih članaka pisano na senzacionalistički način, a naslovi su često vađeni iz konteksta sadržaja članaka. Najviši postotak senzacionalističkih naslova članaka vezanih uz temu ovisnosti ima Večernji list s 54,29\% (19 od 35), slijede 24 sata s $50 \%$ (16 od 32) te Jutarnji list s 40,82 \% (20 od 49).

Večernji list, uz najmanje zastupljenih članaka na temu ovisnosti, ima najveću zastupljenost senzacionalistički orijentiranih članaka. Iz naslova koji glasi „Jeftina sintetička droga flakka zbog koje goli trče po ulicama" (Večernji list, 29.06.2015.: 26) možemo iščitati na koji se način reprezentiraju ovisnici i općenito konzumenti droga. Članak, koji bi na- 
čelno trebao informirati o posljedicama i opasnostima od novih sintetičkih droga, bazira se na kratkom opisu zabilježenih ponašanja pretpostavljenih konzumenata flakka droge, ismijavajući i demonizirajući konzumente te ih nazivajući luđacima i čudacima koji „goli trče po raskrižju, bježeći od začuđenih ljudi, dok je u drugom slučaju čovjek na flakki pokušavao razbiti staklena vrata policijske uprave, a treći se zabijao u metalnu ogradu" (Večernji list, 29.06.2015.: 26). lako ovdje ističemo tekst iz Večernjeg lista kao primjer senzacionalističkog izvještavanja, razina senzacionalističkih naslova visoka je u sva tri analizirana dnevna lista. Tako primjerice u Jutarnjem listu i 24 sata nalazimo naslove poput "Drogirani dečko ubio unuku glumca Morgana Freemana" (Jutarnji list, 18.08.2015.: 25), koji se istog tjedna pojavljuje i u Večernjem listu, s naznakom da je jedino u Jutarnjem listu cijeli slučaj naslovljen tematikom zlouporabe droga.

Rezultati analize vrijednosne orijentacije naslova članaka (vidi tablicu 3) pokazuju da u sva tri dnevna lista prevladavaju neutralni naslovi koji na razini cijelog uzorka zauzimaju prosjek od 61,34 \%, pri čemu dominira Večernji list sa 68,57 \%, dok najmanje neutralnih naslova imaju 24 sata s 56,25\%. Pozitivno orijentiranih naslova je na razini cijelog uzorka $7,12 \%$, pri čemu ih najviše zamjećujemo u Jutarnjem listu - 12,24 \%, a najmanje u Večernjem listu - 2,86 \%. lako je u dominantnom kriminalističkom i psihijatrijskom diskursu, u kojem su članci ponajprije pisani, teško pretpostaviti pozitivnu vrijednosnu orijentaciju, ona bi trebala biti mnogo zastupljenija, a naslovi poput „Ispovijest - pobijedila sam alkoholizam“ (Jutarnji list, 01.03.2015.) i „Od alkoholičara sam postao pobjednik Ol“ (Večernji list, 10.04.2015.) pokazuju na koji se način ovisnost, kao sve rašireniji društveni fenomen, može prikazati kao premostiva prepreka.

Tablica 3. Vrijednosna orijentacija naslova članaka u pregledanim novinama tijekom 2015. godine

\begin{tabular}{lllll} 
Orijentacija & Jutarnji list & Večernji list & 24 sata & Prosjek za sva tri lista \\
\hline Negativno orijentiran & $28,57 \%(14)$ & $28,57 \%(10)$ & $37,50 \%(12)$ & $31,54 \%$ \\
Pozitivno orijentiran & $12,24 \%(6)$ & $2,86 \%(1)$ & $6,25 \%(2)$ & $7,12 \%$ \\
Neutralno orijentiran & $59,18 \%(29)$ & $68,57 \%(24)$ & $56,25 \%(18)$ & $61,34 \%$ \\
Ukupno naslova & 49 & 35 & 32 & $116(100 \%)$ \\
\hline
\end{tabular}

Negativno vrijednosno orijentiranih naslova najviše ima list 24 sata s 37,5 \%, dok Večernji list i Jutarnji list dijele isti postotak: $28,57 \%$. Negativnu vrijednosnu orijentaciju možemo iščitati i u naslovima poput "Mladi na Prozacu su skloni nasilju“ (Jutarnji list, 17.09.2015.: 38), „Bacili bombu u kafić u kojemu je policija dan prije pronašla kokain“ (Večernji list, 02.01.2015.: 18) ili "Maloljetnik dodatni džeparac zarađivao dilanjem tripova" (24 sata, 21.04.2015.: 15). Primjećujemo da se, slično kao i u prijašnjim podacima, riječi vezane uz ovisnost i drogu koriste u negativnim kontekstima sa svrhom isticanja određenih vijesti, a negativna orijentacija naslova može odrediti interpretativna čitanja članaka u smjeru optuživanja i predrasudama obilježenog nekonstruktivnog kritiziranja ovisnika. 


\section{Rezultati analize priloga objavljenih u Mjesecu borbe protiv ovisnosti}

Mjesec borbe protiv ovisnosti u Republici Hrvatskoj obilježava se svake godine od 15. studenog do 15. prosinca, s ciljem upozoravanja javnosti na problem zlouporabe svih oblika sredstava ovisnosti, a osobito psihoaktivnih tvari, „te se time nastoji potaknuti sve subjekte u društvu na aktivnu borbu protiv ovisnosti i zlouporabe droga poduzimanjem zajedničkih aktivnosti za uspješno suprotstavljanje ovom ozbiljnom problemu današnjice" (Vlada RH, 2017).

U poduzorku je analizirano ukupno 75 članaka kojima je tema ovisnost ili sadrže bilo koji pojam vezan uz ovisnost i droge. $U$ odnosu na ispitanih 30 dana, postotak dana s ovakvim člancima najviši je u Jutarnjem listu sa $63,33 \%$, slijede 24 sata s 46,67 \% te Večernji list s najmanjim postotkom od $30 \%$. U usporedbi s uzorkom (Jutarnji list - 75,68 \%, Večernji list $-59,46 \%$ i 24 sata - 54,05 \%), u Mjesecu borbe protiv ovisnosti u sva je tri ispitana lista primjetan manji postotak (sic!).

Rezultati prikazani u tablici 4 razlikuju prosječnu zastupljenost članaka u odnosu na ukupni broj ispitanih članaka podanalize.

Tablica 4. Broj i postotak članaka u Mjesecu borbe protiv ovisnosti u pojedinim novinama

\begin{tabular}{lll} 
Dnevne novine & N & Prosjek \\
\hline Jutarnji list & 37 & $49,33 \%$ \\
Večernji list & 12 & $16,00 \%$ \\
24 sata & 26 & $34,67 \%$ \\
Ukupno & 75 & $100,00 \%$ \\
\hline
\end{tabular}

Naime, kako se vidi u tablici 4, u relaciji s ukupnim brojem ispitanih članaka, najviši postotak članaka vezanih uz ovisnost prisutan je u Jutarnjem listu (49,33\%), a slijedi 24 sata s 34,67 \%. U usporedbi s cijelom godinom, postotak od $16 \%$ u Večernjem listu manji je od godišnjeg prosjeka (30,17 \%), dok je u Jutarnjem listu (42,24 \%) i u 24 sata (27,59 \%) razlika u postotku otišla u korist razdoblja Mjeseca borbe protiv ovisnosti.

U tablici 5 pratimo prosječan broj članaka po izdanju dnevnih novina iz čega je vidljivo da je, u usporedbi s cijelom godinom, u Večernjem listu manje članaka vezanih uz temu ovisnosti od godišnjeg prosjeka koji je iznosio 1,59 članaka po izdanju. Jutarnji list i 24 sata imaju veći broj članaka po izdanju u razdoblju Mjeseca borbe protiv ovisnosti, u prosjeku 0,2 članka dnevno.

Rezultati postotaka senzacionalističkih naslova na temu ovisnosti govore u prilog manje tendencije k senzacionalizmu u analiziranim naslovima tijekom Mjeseca borbe protiv ovisnosti. Većinom prevladavaju naslovi informativne naravi: „Razbijena velika narko mreža u Albaniji“ (Večernji list, 20.11.2015.: 21) ili „Na indoor plantaži uzgajali marihuanu i halucinogene gljive" (Jutarnji list, 26.11.2015.: 22). Najmanje senzacionalističkih naslova u tom 
razdoblju imaju novine 24 sata sa samo 15,38 \%, u kojima se postotak senzacionalističkih naslova, u odnosu na cijelu godinu, izrazito smanjio. U Jutarnjem listu postotak je smanjen s 40,82 \% na 32,43 \%, što je slučaj i s Večernjim listom, koji i dalje ima najveći postotak senzacionalističkih naslova od 41,67\%.

Tablica 5. Prosječan broj članaka po izdanju dnevnih novina u razdoblju Mjeseca borbe protiv ovisnosti

\begin{tabular}{ll} 
Dnevne novine & Prosjek \\
\hline Jutarnji list & 1,95 \\
Večernji list & 1,33 \\
24 sata & 1,86 \\
\hline
\end{tabular}

U Tablici 6 prikazane su vrijednosne orijentacije naslova članaka na temu ovisnosti u razdoblju Mjeseca borbe protiv ovisnosti.

Tablica 6. Vrijednosna orijentacija naslova članaka u tri dnevna lista tijekom Mjeseca borbe protiv ovisnosti

\begin{tabular}{lllll} 
Orijentacija & Jutarnji list & Večernji list & 24 sata & Prosjek za sva tri lista \\
Negativno orijentiran & $29,73 \%(11)$ & $25,00 \%(3)$ & $19,23 \%(5)$ & $24,66 \%$ \\
Pozitivno orijentiran & $13,51 \%(5)$ & $0,00 \%(0)$ & $0,00 \%(0)$ & $4,50 \%$ \\
Neutralno orijentiran & $56,76 \%(21)$ & $75,00 \%(9)$ & $80,77 \%(21)$ & $70,84 \%$ \\
Ukupno naslova & 37 & 12 & 26 & $75(100 \%)$ \\
\hline
\end{tabular}

Kako se vidi u priloženoj tablici, dominiraju neutralno orijentirani naslovi, kao uostalom i na razini cijele godine (v. tablicu 3). U Večernjem listu i 24 sata postotak neutralno orijentiranih članaka veći je u razdoblju Mjeseca borbe protiv ovisnosti, dok Jutarnji list s 56,76\% jedini ima manji postotak u odnosu na cijelu godinu. Večernji list je s $75 \%$ najbliži svom godišnjem postotku od $68,57 \%$, dok 24 sata s postotkom od 80,77 \% najviše odskače od svoga godišnjeg prosjeka koji iznosi 56,25 \%. Pozitivno orijentiranih članaka u Večernjem listu i 24 sata nema, dok su na godišnjoj razini bili zastupljeni s prosjekom od $2,86 \%$ i 6,25 \%. Jutarnji list u razdoblju Mjeseca borbe protiv ovisnosti jedini ima pozitivno orijentirane naslove, njih 13,51 \%, u čemu je prednjačio i na godišnjoj razini s $12,24 \%$. Negativno orijentiranih članaka općenito ima manje u ovom razdoblju. Najviše su zastupljeni u Jutarnjem listu s 29,73\%, koji bilježi rast od $1 \%$, a slijede Večernji list s $25 \%$ i 24 sata s 19,23 \%. 24 sata jedini bilježi smanjenje negativno orijentiranih članaka od otprilike $18 \%$, dok je Večernji list približno na svojoj godišnjoj razini od $28,57 \%$.

Sumiramo li sve rezultate iz Mjeseca borbe protiv ovisnosti dolazimo do podataka da je u svim kategorijama zamjetno pozitivnije prikazana tema ovisnosti. No iako je tema ovisnosti reprezentirana na pozitivan i manje senzacionalistički način, uz veći broj članaka i veću prostornu zastupljenost pojedinih članaka, ne možemo zanemariti podatak da je 
Mjesec borbe protiv ovisnosti eksplicitno spomenut svega dva puta, u dva skromna članka pod naslovima „Po Zagrepčanki trčalo 500 ljudi“ (Jutarnji list, 13.12.2015.: 5) i „Manifestacija 'Baci drogu u koš’ u Puli" (Jutarnji list, 02.12.2015.: 14), koji ukratko izvještavaju o dvije sportske manifestacije kojima se obilježava Mjesec borbe protiv ovisnosti.

\section{ZAKLJUČNI NALAZI}

Provedena analiza upućuje na nekoliko temeljnih zaključaka. U dnevnom tisku nailazimo na relativno veliku količinu medijskog sadržaja koja obuhvaća neke od termina vezanih uz ovisnosti. Međutim, zastupljenosti teme pridonijela je primjena tih termina $u$ svrhe koje nemaju izravne veze sa samim fenomenom ovisnosti. Riječi kao što su diler, droga, heroin i ovisnost nerijetko se koriste tek zato da se opišu događaji iz kriminalnog miljea, crne kronike ili života slavnih. Neusporedivo je manje sadržaja koji se izravno odnose na temu ovisnosti. Kategorija posvećena rubrikama u kojoj se članci nalaze otkriva najčešću zastupljenost teme ovisnosti u crnoj kronici i „nemoralnom“ svijetu slavnih osoba. Stoga su kvantitativni podaci o relativno velikoj zastupljenosti tema sa sadržajima o ovisnosti u vodećim hrvatskim dnevnim novinama u suprotnosti s kvalitativnim uvidima o kontekstualnim aspektima tih sadržaja.

Sadržaji u kojima se spominje tema ovisnosti različito su vrijednosno orijentirani. Većina analiziranih članaka obilježena je neutralnom vrijednosnom orijentacijom. Zamjetan je postotak negativno orijentiranih naslova članaka, približno $30 \%$, no indikativno je to da je izrazito nizak postotak pozitivno orijentiranih naslova članaka. Pozitivna orijentacija naslova članaka pretežno je usmjerena na izvještavanje o učincima medicinskog kanabisa, dok je nekoliko primjera rehabilitacije i resocijalizacije ovisnika prisutno u tjednim prilozima pojedinih novina. Neutralnost sadržaja često proizlazi iz kvantitativno manjih članaka, gdje ograničenja količine teksta zahtijevaju kratke i šture podatke koji kreiraju neutralan tip diskursa.

No, kao što i Robert McChesney (2014) ističe, novinarstvo nije politički neutralno, nego pod geslom autonomije i objektivnosti „krijumčari” vrijednosti koje odgovaraju komercijalnim, ali i političkim ciljevima medijskih vlasnika, oglašivača i kreditora. Ben Bagdikian je još 1980-ih opisao taj fenomen riječima "kopaj tamo, ne ovdje”, upozoravajući time na mehanizam kojim kriminalističke priče iz crnih kronika prelaze u rubrike vijesti, a trivijalnosti iz života slavnih postaju legitimnim novinarstvom (Bagdikian, 1983). Neutralnost sadržaja podržava poželjnu atmosferu oglašavanja u kojoj plodno tlo nalaze "naredbe za umetanje" (engl. insertion orders), jasni naputci tvrtki oglašivača o tome koje to teme i pristupe treba izbjegavati ukoliko mediji žele da one zakupe njihove oglasne prostore. Tendencije da se zadovolje očekivanja oglašivača, novinara i urednika stvaraju efekt tzv. „potrošačkog raspoloženja” (engl. buying mood) ili „podržavajuće uređivačke atmosfere“ (engl. supportive editorial atmosphere) (Hromadžić, 2014: 10).

Tijekom cijele godine naslovi i sadržaji članaka u velikoj su mjeri senzacionalistički intonirani te se vijesti vezane uz temu ovisnosti često oblikuju kroz iskazivanje neistina i izokretanja stvarnih činjenica. U prosjeku oko 50 \% članaka u sva tri dnevna lista u kojima 
se spominje neki aspekt ovisnosti ili bilo koji pojam vezan uz ovisnost i droge senzacionalistički izvještava o segmentu ovisničkog fenomena. Veliki dio cjelokupnog medijskog prostora senzacionalistički je intoniran, od pojedinosti iz života slavnih osoba, detaljnih opisa prometnih nesreća uzrokovanih konzumacijom opojnih sredstava pa sve do priča prikazanih kao istinite i navodno potvrđene informacije. Novinari i urednici često ne poštuju novinarsku etiku te senzacionalističkim pisanjem doprinose trivijalnom i neprofesionalnom prikazu marginaliziranih skupina, s posljedicama neprikladnog informiranja javnosti o problemu ovisnosti.

Načini na koje se prikazuju posljedice drogiranja dodatno potvrđuju tezu o stigmatizaciji ovisnika. Tema ovisnosti najčešće se nalazi u okviru sadržaja koji se tiču kriminalnih i kažnjivih radnji. Članci se mahom odnose na zapljene narkotika, remećenje javnog reda, prometne prekršaje i nesreće, sudske presude „dilerima“. Posljedice drogiranja predstavljaju se kroz povećanje kriminaliteta i devijantnog ponašanja (nasilnici, razbojnici, lopovi, huligani), gubitak zaposlenja, obiteljske tragedije, štetnosti za zdravlje i životne brodolome slavnih osoba. Negativna konotacija ovisnika često je korištena prilikom analiziranja profila terorista, a njihovi postupci često se vezuju uz konzumiranja opojnih sredstava.

Dodatna analiza sadržaja članaka objavljenih u Mjesecu borbe protiv ovisnosti potvrdila je obrazac senzacionalističkog izvještavanja i količinu zastupljenosti sadržaja vezanih uz temu ovisnosti. U analiziranom razdoblju postoje odstupanja od godišnjeg prosjeka kada je riječ o količini neutralnih, negativnih i pozitivnih vrijednosnih orijentacija naslova članaka. Razloge za takve rezultate ne treba tražiti u činjenici prikladnijeg pristupa temi ovisnosti u mjesecu posvećenom borbi protiv ovisnosti, već u razlikovanju uzoraka koji su analizirani. Na godišnjoj razini uzorak je bio slučajni (svaki deseti dan), dok je u podanalizi Mjeseca borbe protiv ovisnosti analiziran sadržaj svakoga dana, pri čemu treba znati da dnevni tisak uključuje određene razlike koje se tiču tipova priloga i strukture dnevnih izdanja tijekom pojedinih dana u tjednu (vikend-izdanja, tjedni prilozi).

Smatramo kako rezultati analize mogu ukazati na putanje kreiranja općeg medijskog okvira (media frame) fenomena ovisnosti koji medijski sadržaji popunjavaju. Na kraju istraživanja možemo zaključiti da su medijski sadržaji u kojima se spominje neki aspekt ovisnosti ili bilo koji pojam vezan uz ovisnost i droge u hrvatskom dnevnom tisku natprosječno zastupljeni u kvantitativnom, ali su potkapacitirani u kvalitativnom smislu; pretežito su označeni neutralnim vrijednosnim obilježjima, uz zamjetno izražen senzacionalistički obol.

Konačno, na razini značenja, diskurs vijesti određuje ne samo ono što je u vijestima nego i ono što je odsutno, što nije izabrano za vijest i potisnuto je iz diskursa. Resocijalizacija ovisnika, pozitivni primjeri zapošljavanja, osnivanja i održavanja obitelji, volontiranja i pomaganja potrebitima jesu teme koje se ne nalaze u pregledanim dnevnim novinama. Kako narav diskursa vijesti podrazumijeva da novinarske reprezentacije društvenih zbivanja potječu iz društva, prikaz stvarnog putem novinarskih praksi mora se kontinuirano dovoditi u pitanje. 


\section{Literatura}

>Bagdikian, Ben (1983) The Media Monopoly. Boston: Beacon Press.

>Bennett, Tony (1982) Media, "reality", signification, str. 285-306, u: Bennett, Tony, Gurevitch, Michael, Curran, James i Woollacott, Janet (ur.) Culture, Society and the Media. London:

Methuen Routledge.

>Bognar, Ladislav (2005) Pedagoški aspekt problema ovisnosti kod mladih. Pedagogijska

istraživanja 2 (1): 113-124.

>Bratić, Andreja (2014) Rezultati istraživanja Ipsos Puls-a - Jutarnji list najčitanija tiskovina za sedam kuna u Hrvatskoj. 28. kolovoza 2014. http://www.jutarnji.hr/vijesti/hrvatska/rezultati-istrazivanjaipsos-puls-a-jutarnji-list-najcitanija-tiskovina-za-sedam-kuna-u-hrvatskoj/692086/ (01.09.2016.). $>$ Cohen, Stanley (2002) Folk Devils and Moral Panic: The Creation of the Mods and Rockers. London i New York: Routledge.

>Dragojević, Sanjin; Kanižaj, Igor i Žebec, Ivana (2004) Medijska analiza odabranih tiskovina na temu stranih poduzetnika u Hrvatskoj. Društvena istraživanja 13 (1-2): 97-122.

$>$ Goode, Erich (2014) Drugs in American Society. New York: McGraw-Hill Education.

$>$ Goode, Erich i Ben-Yehuda, Nachman (2009) Moral Panics: The Social Construction of Deviance. New Jersey: Wiley-Blackwell. DOI: 10.1002/9781444307924.

$>$ Grant, Jon E.; Potenza, Marc N.; Weinstein, Aviv i Gorelick, David A. (2010) Introduction to Behavioral Addictions. The American Journal of Drug and Alcohol Abuse 36 (5): 233-241.

$>$ Harley, Trevor A. (2007) The Psychology of Language: From Data to Theory. Hove: Psychology Press. DOI: $10.4324 / 9780203345979$.

>Hromadžić, Hajrudin (2014) Medijska konstrukcija društvene zbilje: Socijalno-ideološke implikacije produkcije medijskog spektakla. Zagreb: AGM.

$>$ Hromadžić, Hajrudin (2013) Politika, društvo spektakla i medijska konstrukcija realnosti. Politička misao 50 (2): 60-74.

>llišin, Vlasta; Bouillet, Dejana; Gvozdanović, Anja i Potočnik, Dunja (2013) Mladi u vremenu krize: prvo istraživanje IDIZ-a i Zaklade Friedrich Ebert o mladima / Youth in a Time of Crisis: First IDIZFriedrich-Ebert-Stiftung Youth Survey.

>llišin, Vlasta; Marinović Bobinac, Ankica i Radin, Furio (2001) Djeca i mediji. Zagreb: Državni zavod za zaštitu obitelji, materinstva i mladeži.

>Lalić, Dražen (1995) Ekonomska reprodukcija ovisnosti o heroinu - Split devedesetih godina.

Revija za sociologiju 26 (3-4): 209-218.

>Leburić, Anči i Relja, Renata (2001) U potrazi za dobrom zabavom: istraživanje noćnog života mladih u diskoklubovima na području primorskih županija. Društvena istraživanja 10 (56): 1083-1107. $>$ Malović, Stjepan (ur.) (2007) Vjerodostojnost novina. Zagreb: ICEJ i Sveučilišna knjižara.

>McChesney, Robert W. (2014) Digitalna isključenost: kako kapitalizam okreće internet protiv demokracije. Zagreb: Multimedijalni institut i Beograd: Fakultet za medije i komunikacije.

$>$ Nenadić Bilan, Diana (2012) Strategije prevencije ovisnosti o drogama. Magistra ladertina 7 (1): 35 53. DOI: 10.15291/magistra.814.

>Pačić-Turk, Ljiljana i Bošković, Gordana (2008) Prevencija ovisnosti s aspekta teorije socijalnog učenja i kognitivne psihologije. Klinička psihologija 1 (1-2): 39-57.

>Popović, Helena (2014) Značaj medijskog integriteta - vraćanje medija i novinarstva u službu javnosti. Zagreb: Centar za istraživačko novinarstvo.

>PoslovniPuls (2015) Tko će uređivati Hanžekovićev Jutarnji list. http://www.poslovnipuls. com/2015/01/15/evo-tko-ce-uredivati-hanzekovicev-jutarnji-list/ (04.09.2016.).

$>$ Stephens, Mitchell (2007) A History of News. New York: Oxford University Press.

$>$ Udruga Vida (2016) http://www.droga-online.com.hr/ (07.09.2016.).

$>$ Vlada RH (2017) Mjesec borbe protiv ovisnosti (15. 11. - 15. 12.). Ured za suzbijanje zlouporabe droga. https://drogeiovisnosti.gov.hr/istaknute-teme/obiljezavanje-vaznih-datuma/mjesec-borbe-protivovisnosti-15-11-15-12/978 (07.09.2016.). 
>Vlada RH (2015) Izvješće o evaluaciji Projekta resocijalizacije ovisnika o drogama. Zagreb: Vlada Republike Hrvatske, Ured za suzbijanje zlouporabe droga.

$>$ Vozab, Dina (2014) Tisak u krizi: analiza trendova u Hrvatskoj od 2008. do 2013. Medijske studije 5 (10): 139-147.

\section{Analizirani i citirani novinski članci}

$>$ Jutarnji list

01. 03. 2015.: „Ispovijest - pobijedila sam alkoholizam"

20. 05. 2015.a: „10 CM KRAĆl: Dječaci koji puše „travu“ manje rastu“

20. 05. 2015.b: „Drogirani par divljao držeći bebu“

18. 08. 2015.: "Drogirani dečko ubio unuku glumca Morgana Freemana"

07. 09. 2015.: "U Hrvatskoj se pere golemi novac moćnih narkokartela"

17. 09. 2015.: "Mladi na Prozacu su skloni nasilju“

27. 09. 2015.: "Kako nam je marihuana spasila živote"

26. 11. 2015.: "Na indoor plantaži uzgajali marihuanu i halucinogene gljive"

02. 12. 2015.: "Manifestacija 'Baci drogu u koš' u Puli“

13. 12. 2015.: „Po Zagrepčanki trčalo 500 ljudi“

$>$ Večernji list

02. 01. 2015.: „Bacili bombu u kafić u kojemu je policija dan prije pronašla kokain“

31 .03. 2015.: „Policija spaljivala marihuanu pa se pola grada napušilo"

10. 04. 2015.: "Od alkoholičara sam postao pobjednik Ol"

29. 06. 2015.: "Jeftina sintetička droga flakka zbog koje goli trče po ulicama“

18. 08. 2015.: "Mitovi o kanabisu"

27. 10. 2015.: "Mladi par umro nakon pira od nove smjese narkotika"

20. 11. 2015.: „Razbijena velika narko mreža u Albaniji“

$>24$ sata

31. 01. 2015.: „Djed (63): Marihuana je bakina, ja joj uopće nisam pomagao“

20. 02. 2015.: "Dječak pušio osvježivač zraka, poplavio i umro?"

21. 04. 2015.: "Maloljetnik dodatni džeparac zarađivao dilanjem tripova"

20. 07. 2015.: "Nova droga u gumenim bombonima" 


\title{
MEDIA REPRESENTATION OF DRUG ADDICTS AND DRUG ADDICTION IN THE CROATIAN DAILY PRESS
}

\section{Ljiljana Kordić :: Hajrudin Hromadžić :: Jurica Karlić}

\begin{abstract}
This article articulates and examines the problem of how to represent addicts and addiction in media content. The authors conduct a quantitative and qualitative content analysis of selected daily press in Croatia (Jutarnji list, Večernji list and 24 sata) from 2015 and a sub-analysis of the target period (Anti-addiction Month) serving to compare two different news cycles. The media coverage of the examined themes, the connotation of such media content and the approach to this issue are analysed. This article provides insight into how addiction, as well as drug addicts, is represented in the selected media, and the implications and consequences such representations carry with them, while exploring the questions such as why these types of representations are present, and whose interests are represented in such representations.
\end{abstract}

KEY WORDS

DRUG ADDICTS, DRUG ADDICTION, MEDIA, REPRESENTATIONS, SENSATIONALISM

Authors note

Ljiljana Kordić :: Drug Abuse Treatment Association „Vida“, Rijeka, Croatia :: ljkordic@gmail.com Hajrudin Hromadžić :: University of Rijeka, Faculty of Social Sciences and Humanities, Croatia :: hhromadzic@ffri.hr

Jurica Karlić :: independent researcher, Croatia :: jurica.karlic@gmail.com 